\title{
Selective fluorescent probes for live-cell monitoring of sulphide
}

\author{
Yong Qian ${ }^{1,2, \star}$, Jason Karpus ${ }^{1, \star}$, Omer Kabil ${ }^{3}$, Shu-Yu Zhang ${ }^{1,4}$, Hai-Liang Zhu², Ruma Banerjee ${ }^{3}$, Jing Zhao ${ }^{2}$ \& \\ Chuan $\mathrm{He}^{1}$
}

Aqueous sulphides, including hydrogen sulphide, have important roles in biological signalling and metabolic processes. Here we develop a selective sulphide-trapping strategy involving sulphide addition to an aldehyde; the resulting hemithioacetal undergoes a Michael addition with an adjacent unsaturated acrylate ester to form a thioacetal at neutral $\mathrm{pH}$ in aqueous solution. Employing this new strategy, two sulphide-selective fluorescent probes, SFP-1 and SFP-2, were synthesized on the basis of two different fluorophore templates. These probes exhibit an excellent fluorescence increase and an emission maximum shift (SFP-1) in response to $\mathrm{Na}_{2} \mathrm{~S}$ and $\mathrm{H}_{2} \mathrm{~S}$ in a high thiol background as found under physiological conditions. We show the utility of the probes for the selective detection of sulphides, and the capacity of our probes to monitor enzymatic $\mathrm{H}_{2} \mathrm{~S}$ biogenesis and image free sulphide in living cells.

\footnotetext{
${ }^{1}$ Department of Chemistry and Institute for Biophysical Dynamics, The University of Chicago, 929 East 57th Street, Chicago, IIlinois 60637, USA. ${ }^{2}$ State Key Laboratory of Pharmaceutical Biotechnology, School of Life Sciences, Nanjing University, Nanjing 210093, China. ${ }^{3}$ Department of Biological Chemistry, University of Michigan Medical School, Ann Arbor, Michigan 48109-0600, USA. ${ }^{4}$ State Key Laboratory of Applied Organic Chemistry and Department of Chemistry, Lanzhou University, Lanzhou 730000, China. ${ }^{*}$ These authors contributed equally to the work. Correspondence and requests for materials should be addressed to C.H. (email: chuanhe@uchicago.edu).
} 
$\mathrm{H}$ ydrogen sulphide $\left(\mathrm{H}_{2} \mathrm{~S}\right)$, along with nitric oxide $(\mathrm{NO})$ and carbon monoxide (CO), belongs to the gasotransmitter family of signalling molecules in biology ${ }^{1,2} \cdot \mathrm{H}_{2} \mathrm{~S}$, or aqueous sulphide, elicits diverse physiological responses, including modulation of blood pressure and reduction of ischemia reperfusion injury ${ }^{3-5}$, exertion of anti-inflammatory effects ${ }^{6}$ and reduction of metabolic rate ${ }^{7}$. The production of $\mathrm{H}_{2} \mathrm{~S}$ is catalysed by the two pyridoxal $5^{\prime}$-phosphate-dependent enzymes, cystathionine $\beta$-synthase $(\mathrm{CBS})^{8}$, and cystathionine $\gamma$-lyase ${ }^{9}$, and indirectly, via a pyridoxal $5^{\prime}$-phosphateindependent enzyme, 3-mercaptopyruvate sulphurtransferase ${ }^{10}$.

The lack of methods for accurate measurement of $\mathrm{H}_{2} \mathrm{~S}$ has limited advances in the field. As a result of the technical limitations of available methods ${ }^{11,12}, \mathrm{H}_{2} \mathrm{~S}$ concentrations spanning $10^{5}$ orders of magnitude have been reported in the literature ${ }^{13}$. Moreover, many of the commonly used methods are not amenable for application in vivo or for analysis of tissue or blood samples. Until recently, no probe was available for the detection of aqueous sulphides in vivo (while this manuscript was under review, a related probe was reported ${ }^{14}$ ). A major challenge is to develop molecular probes that are capable of detecting aqueous sulphides $\left(\mathrm{H}_{2} \mathrm{~S}\right.$ and $\mathrm{HS}^{-}$at neural $\left.\mathrm{pH}\right)$ in the presence of other cellular molecules, in particular, millimolar concentrations of thiols found inside most cells. Recently, a thiolmaleimide reaction was employed to tune photoinduced electron transfer of a conjugated fluorophore for thiol detection and imaging $^{15}$. Although effective for detection of abundant thiol molecules, this method is unable to differentiate sulphide from thiols.

Partially inspired by this previous work, we envisioned an aromatic framework substituted by $\alpha, \beta$-unsaturated acrylate methyl ester and aldehyde (-CHO) ortho to each other. The aldehyde group can react readily and reversibly with free sulphide to form a hemithioacetal intermediate with an exposed thiol, which is set up for a Michael addition to the proximal acrylate to yield a trapped thioacetal. This tandem reaction could tune photoinduced electron transfer of the aromatic system, thus potentially affecting fluorescence of a conjugated fluorophore. As reversible addition of a thiol to the same aldehyde yields a thioacetal that cannot perform the subsequent Michael addition step, the intermediate simply decomposes to yield the original probe, thus it will not significantly interfere sulphide detection. In addition, $\mathrm{H}_{2} \mathrm{~S}$ in aqueous solution has a $\mathrm{pK}_{\mathrm{a}}$ of $\sim 7.0$, whereas thiols have higher $\mathrm{pK}_{\mathrm{a}}$ values around 8.5. Hence, aqueous sulphide is expected to be a better nucleophile at neutral $\mathrm{pH}$ than free thiols. In this study, we report the development of two highly sulphide-selective fluorescent probes (SFP-1 and SFP-2), using a chemical strategy for effective in vivo and in vitro detection of $\mathrm{H}_{2} \mathrm{~S}$. We demonstrate the utility of the probe in enzymatic $\mathrm{H}_{2} \mathrm{~S}$ quantification and cell-based imaging applications.

\section{Results}

Synthesis and fluorescent measurements of SFP-1. We selected 1,3,5-triaryl-2-pyrazoline as the first fluorophore template because its fluorescence is sensitive to the electronic changes of the substituted aromatic groups ${ }^{16}$. During synthesis of the probe, we inadvertently obtained 1,3,5-triaryl-pyrazole because of a required oxidation step (Fig. 1). The final probe 12 (SFP-1) was characterized by nuclear magnetic resonance (NMR), mass spectrometry and X-ray crystallography (CCDC 843032; Supplementary Figs S1-S3, Supplementary Tables S1-S5, Supplementary Data 1). The phenyl substitution at $\mathrm{C} 5$ of the pyrazole core is designed to react with sulphide to afford 12a (Fig. 2), thus yielding a fluorescence change.

Reaction of probe $12(10 \mu \mathrm{M})$ with $\mathrm{Na}_{2} \mathrm{~S}(50 \mu \mathrm{M})$ as an aqueous sulphide source at $37^{\circ} \mathrm{C}$ in $\mathrm{PBS}$ buffer ( $\mathrm{pH}$ 7.4) yielded a timedependent fluorescence increase, which was completed within 60 min (Fig. 2a, Supplementary Fig. S4). A >10-fold increase in the fluorescence intensity accompanied by a blue shift in the emission<smiles>COC(=O)c1cc(Br)c(C2OCCCO2)c(C2OCCCO2)c1C(=O)O</smiles><smiles>O=C(/C=C/c1ccc(C2OCCCO2)c(Br)c1)c1cc(F)cc(F)c1</smiles>

7

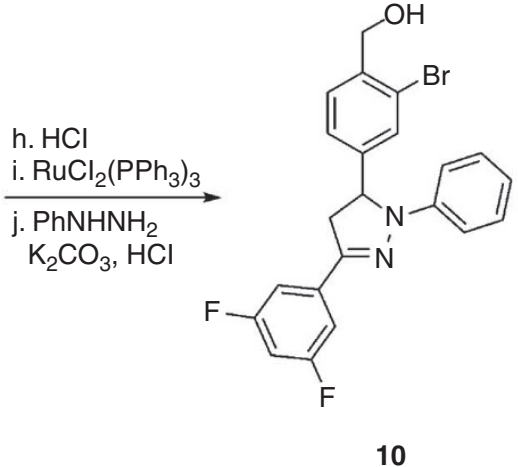

10

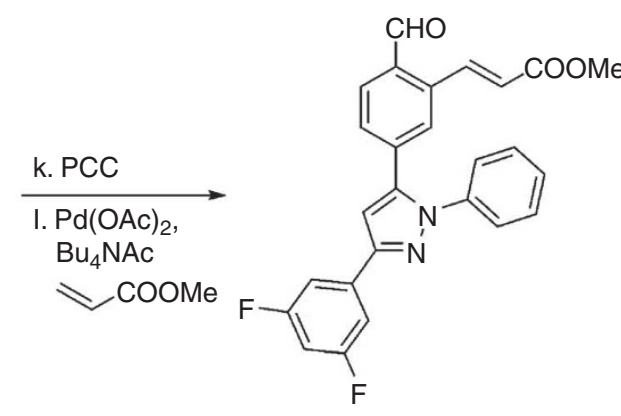

12 (SFP-1)

Figure 1 | Probe SFP-1 synthesis. (a) $\mathrm{MeOH}_{1} \mathrm{H}_{2} \mathrm{SO}_{4}$ (2.0 equivalent), $80^{\circ} \mathrm{C}, 12 \mathrm{~h}, 87 \%$; (b) $\mathrm{CrO}_{3}$ (3 equiv.), $\mathrm{AcOH}$ (30 equiv.), $\mathrm{Ac} c_{2} \mathrm{O}$ (18 equiv.) $\mathrm{H}_{2} \mathrm{SO}_{4}$ (4.5 equiv.) $0^{\circ} \mathrm{C}, 1 \mathrm{~h}, 57 \%$; (c) $\mathrm{H}_{2} \mathrm{SO}_{4}, \mathrm{MeOH} / \mathrm{H}_{2} \mathrm{O}(1: 1), 100^{\circ} \mathrm{C}, 30 \mathrm{~min}$, then $\mathrm{THF}, \mathrm{HCl}, 80^{\circ} \mathrm{C}, 2 \mathrm{~h}, 78 \%$; (d) 1,3 -propanediol (6 equiv.), $p$ - $\mathrm{TsOH}$ ( 0.35 equiv.), anhydrous $\mathrm{Na}_{2} \mathrm{SO}_{4}, 80^{\circ} \mathrm{C}, 24 \mathrm{~h}, 80 \%$; (e) $\mathrm{NaBH}_{4}$ (10 equiv.), 1, 4-dioxane/ $\mathrm{H}_{2} \mathrm{O}(3: 2), 65^{\circ} \mathrm{C}, 12 \mathrm{~h}, 70 \%$; (f) $\mathrm{PCC}\left(1.5\right.$ equiv.), celite, $\mathrm{CH}_{2} \mathrm{Cl}{ }_{2}, 25^{\circ} \mathrm{C}$, 1h, 90\%; (g) 3', $5^{\prime}$-difluoroacetophenone (1.1 equiv.), $5 \mathrm{~N} \mathrm{NaOH}$ (20 equiv.), EtOH, $25^{\circ} \mathrm{C}, 2 \mathrm{~h}, 91 \%$; (h) HCl, $\mathrm{THF}^{2}, 25^{\circ} \mathrm{C}, 5 \mathrm{~h}, 99 \%$; (i) RuCl$\left(\mathrm{PPh}_{3}\right)_{3}(0.7 \%$ equiv.), $\mathrm{HCOOH}$ (2.8 equiv.), $\mathrm{Et}_{3} \mathrm{~N}\left(1.7\right.$ equiv.), $\mathrm{THF}, 25^{\circ} \mathrm{C}, 2 \mathrm{~h}, 83 \%$; (j) phenylhydrazine (1.3 equiv.), $\mathrm{HCl}\left(1.3\right.$ equiv.), $\mathrm{K}_{2} \mathrm{CO}_{3}\left(0,25\right.$ equiv.), $\mathrm{EtOH}, 90^{\circ} \mathrm{C}$, $12 \mathrm{~h}, 65 \%$; (k) PCC (5 equiv.), celite, $\mathrm{CH}_{2} \mathrm{Cl}_{2}, 25^{\circ} \mathrm{C}, 2 \mathrm{~h}, 86 \%$; (I) Pd(OAc) (0.1 equiv.), methyl acrylate (1.2 equiv.), $\mathrm{Bu}_{4} \mathrm{NAc}_{2}\left(3 \mathrm{equiv}\right.$.), $\mathrm{K}_{2} \mathrm{CO}_{3}(1.5$ equiv.), $\mathrm{KCl}\left(1.5\right.$ equiv.), $\mathrm{DMF}, 90^{\circ} \mathrm{C}, 2 \mathrm{~h}, 56 \%$. DMF, $\mathrm{N}, \mathrm{N}$-dimethylformamide; $\mathrm{Et}_{3} \mathrm{~N}$, triethylamine; $\mathrm{NaBH}_{4}$, sodium borohydrid; $\mathrm{PCC}$, pyridinium chlorochromate; THF, tetrahydrofuran; $p$ - $\mathrm{TsOH}, p$-toluenesulfonic acid. 
<smiles>COC(=O)/C=C/c1cc(-c2cc(-c3cc(F)cc(F)c3)nn2-c2ccccc2)ccc1C=O</smiles>
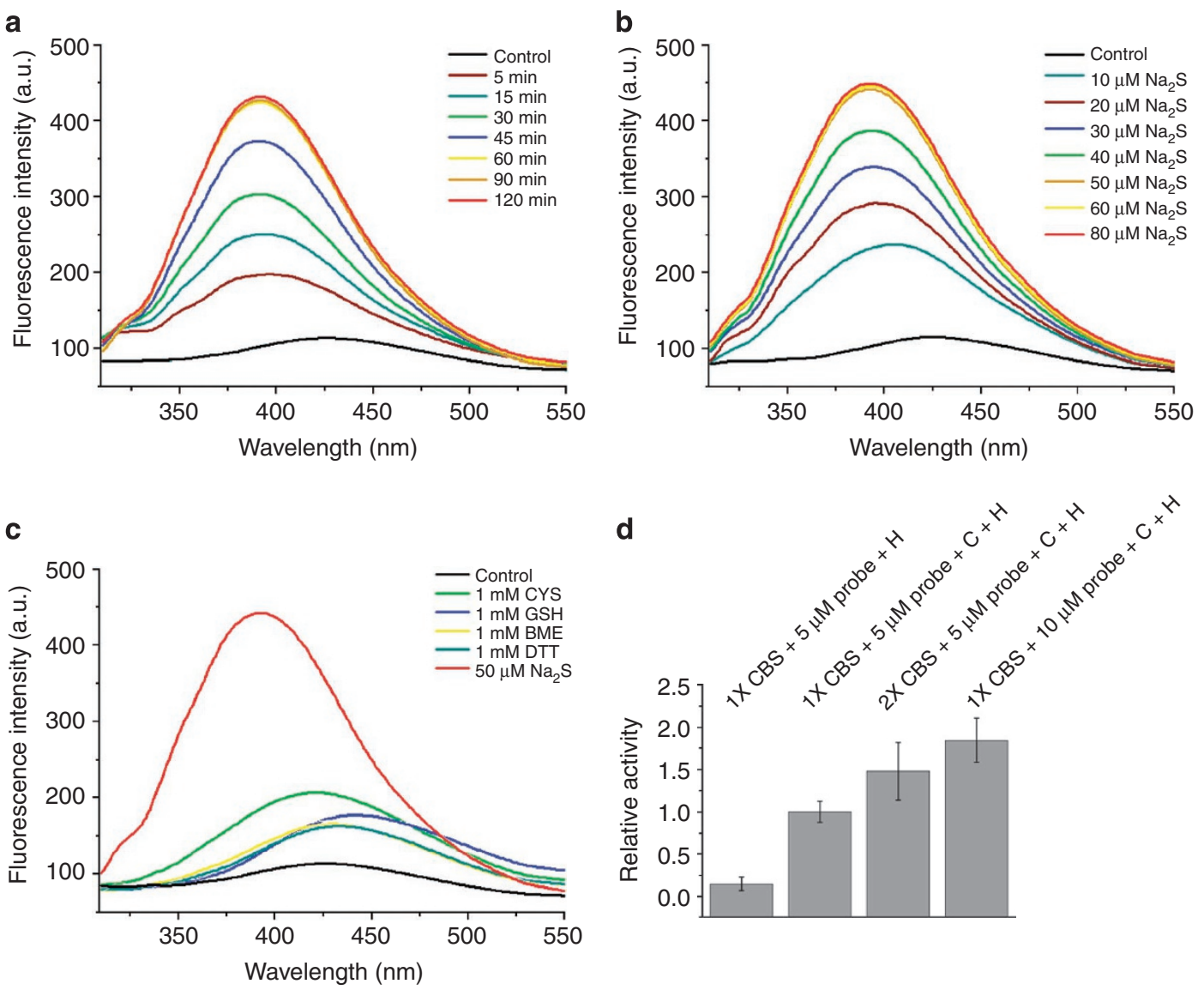

Figure 2 | SFP-1 reacts with sulphide to give a turn-on fluorescence response. (a-c) Fluorescence spectra of the SFP-1 probe (10 $\mu$ M) in PBS buffer (10 mM, pH 7.4, $10 \% \mathrm{CH}_{3} \mathrm{CN}$ ) at $37^{\circ} \mathrm{C}$ for $60 \mathrm{~min}$. Excitation: $300 \mathrm{~nm}$, emission: $310-550 \mathrm{~nm}$. The data represent the average of three independent experiments. (a) Incubated with $50 \mu \mathrm{M} \mathrm{Na}_{2} \mathrm{~S}$ after 5, 15, 30, 45, 60, 90 and $120 \mathrm{~min}$. (b) Incubated with different concentrations of $\mathrm{Na}_{2} \mathrm{~S}(10,20,30,40,50$, 60 and $80 \mu \mathrm{M}$ ). (c) Incubated with various thiols at $1 \mathrm{mM}$ (CYS, cysteine; BME, 2-mercaptoethanol; DTT, dithiothreitol). (d) Fluorescent detection of $\mathrm{H}_{2} \mathrm{~S}$ generation by CBS. Human CBS was mixed with either homocysteine $(\mathrm{H})$ or cysteine $(\mathrm{C})$ + homocysteine (10 mM each). The $\mathrm{H}_{2} \mathrm{~S}$-producing activity of $\mathrm{CBS}$ in the presence of cysteine and homocysteine and $5 \mu \mathrm{M}$ probe was set at 1 and the data represent the mean \pm s.d. of at least three independent experiments.

maximum from 428 to $391 \mathrm{~nm}$ was observed $\left(\varepsilon=2,320 \mathrm{M}^{-1} \mathrm{~cm}^{-1}\right.$, $\Phi=0.058$ ). Addition of sulphide most likely eliminates the quenching effects of the conjugated, unsaturated acrylate ester and aldehyde on the 5-substituted phenyl group. Consistently, a blue shift of emission indicates a break of conjugation of SFP-1 on sulphide addition. We isolated product $\mathbf{1 2 a}$ and confirmed its molecular formula by high-resolution mass spectrometry (Supplementary Fig. S3).

Next, varying concentrations of $\mathrm{Na}_{2} \mathrm{~S}(10-50 \mu \mathrm{M})$ were added to the test reaction solution. The fluorescence intensity increased linearly with the concentration of $\mathrm{Na}_{2} \mathrm{~S}$ up to $50 \mu \mathrm{M}$ (Supplementary Fig. S5), and, thereafter, reached a steady state (Fig. 2b). To characterize the direct response of the probe towards $\mathrm{H}_{2} \mathrm{~S}$, the probe was added to a buffered solution that had been bubbled with $\mathrm{H}_{2} \mathrm{~S}$ gas. The presence of low concentrations of $\mathrm{H}_{2} \mathrm{~S}$ led to a significant fluorescence change, confirming the utility of SFP-1 for monitoring aqueous $\mathrm{H}_{2} \mathrm{~S}$ (Supplementary Fig. S6). The specificity of the probe was examined by measuring its response after exposure to various thiols in PBS buffer. Strikingly, even at high concentrations (1 mM), the response of SFP-1 to any of the tested thiols was very low, exhibiting at least 50 - to 100-fold selectivity towards sulphide (Fig. 2c). In addition, the emission maximum of $\mathbf{1 2 a}$ is different from those of potential thiol addition products; monitoring emission at lower wavelength should allow further distinction between sulphide versus thiol adducts. For instance, if emission can be monitored at $350 \mathrm{~nm}$, the most abundant thiol in mammalian cells, glutathione, does not interfere with sulphide, thus providing potential superb selectivity for sulphide detection and imaging.

To investigate whether the probe can be used to monitor enzymatic $\mathrm{H}_{2} \mathrm{~S}$ generation, we tested its efficacy with recombinant human CBS (Fig. 2d). $\mathrm{H}_{2} \mathrm{~S}$ production by CBS was readily detected in the presence of millimolar concentrations of the thiol substrates, homocysteine and/or cysteine. Doubling CBS concentration or the 


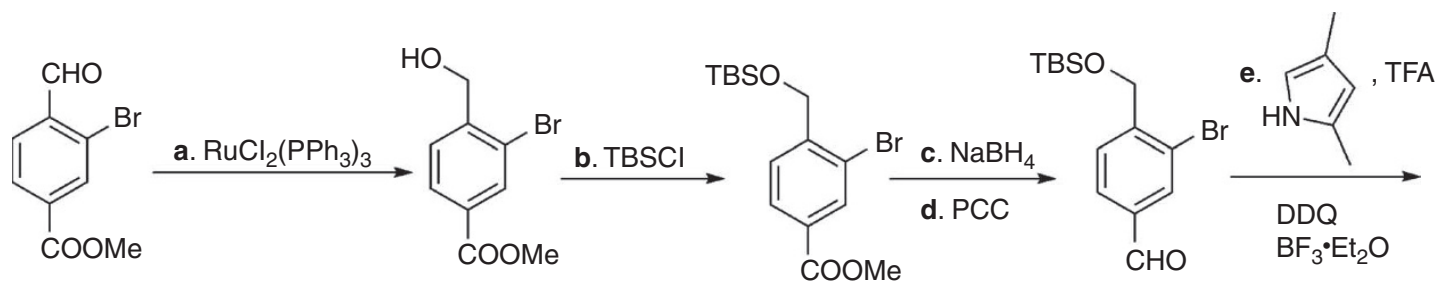

3

13

14

16<smiles></smiles>

17
17

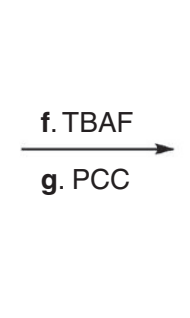<smiles></smiles>

19

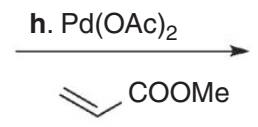<smiles></smiles>

20 (SFP-2)

Figure 3 | Probe SFP-2 synthesis. (a) $\mathrm{RuCl}_{2}\left(\mathrm{PPh}_{3}\right)_{3}\left(0.7 \%\right.$ equivalent), $\mathrm{HCOOH}$ (2.8 equiv.), $\mathrm{Et}_{3} \mathrm{~N}\left(1.7\right.$ equiv.), $\mathrm{THF}, 25^{\circ} \mathrm{C}, 2 \mathrm{~h}, 92 \% ;(\mathbf{b}) \mathrm{TBSCl}(1.2 \mathrm{equiv}$.), imidazole (2 equiv.), DMF, $25^{\circ} \mathrm{C}, 12 \mathrm{~h}, 99 \%$; (c) $\mathrm{NaBH}_{4}$ (10 equiv.), 1, 4-dioxane $/ \mathrm{H}_{2} \mathrm{O}(3: 2), 65^{\circ} \mathrm{C}, 12 \mathrm{~h}, 72 \%$; (d) $\mathrm{PCC}\left(1.5\right.$ equiv.), celite, $\mathrm{CH}_{2} \mathrm{Cl}{ }_{2}, 25^{\circ} \mathrm{C}$, 1h, 64\%; (e) (1) 2,4-dimethylpyrrole (2 equiv.), TFA (one drop), $\mathrm{CH}_{2} \mathrm{Cl}_{2}, 25^{\circ} \mathrm{C}, 12 \mathrm{~h}$. (2) DDQ (1 equiv.), $\mathrm{CH}_{2} \mathrm{Cl}_{2}, 25^{\circ} \mathrm{C}, 1 \mathrm{~h}$. (3) DIPEA (10 equiv.), $\mathrm{BF}_{3} \cdot \mathrm{Et}_{2} \mathrm{O}$ (30 equiv.), $\mathrm{CH}_{2} \mathrm{Cl}_{2}, 25^{\circ} \mathrm{C}, 2 \mathrm{~h}, 58 \%$; (f) $\operatorname{TBAF}\left(1\right.$ equiv.), $\mathrm{THF}, 25^{\circ} \mathrm{C}, 30 \mathrm{~min}, 83 \%$; (g) PCC (5 equiv.), $\mathrm{MgSO}_{4}, \mathrm{CH}_{2} \mathrm{Cl}_{2}, 25^{\circ} \mathrm{C}, 30 \mathrm{~min}, 65 \%$; (h) $\mathrm{Pd}(\mathrm{OAc})_{2}$ (0.1 equiv.), methyl acrylate (4 equiv.), $\mathrm{PPh}_{3}$ (0.3 equiv.), $\mathrm{Et}_{3} \mathrm{~N}$ (1.5 equiv.), $\mathrm{CH}_{3} \mathrm{CN}, 90^{\circ} \mathrm{C}, 12 \mathrm{~h}, 38 \%$. DDQ, 2,3-Dichloro-5,6-dicyano-pbenzoquinone; DIPEA, N, N-Diisopropylethylamine; $\mathrm{DMF}, \mathrm{N}, \mathrm{N}$-dimethylformamide; $\mathrm{Et}_{3} \mathrm{~N}$, triethylamine; $\mathrm{NaBH}_{4}$, sodium borohydrid; $\mathrm{PCC}$, pyridinium chlorochromate; TBAF, Tetrabutylammonium fluoride trihydrate; TBSCl, tert-Butyl(chloro)dimethylsilane; TFA, Trifluoroacetic acid; THF, tetrahydrofuran.

probe concentration (from 5 to $10 \mu \mathrm{M}$ ) resulted in increased signal intensity. These results demonstrate the excellent selectivity of the probe to $\mathrm{H}_{2} \mathrm{~S}$ in a high thiol background and its utility as a molecular probe for detecting $\mathrm{H}_{2} \mathrm{~S}$ biogenesis in in vitro assays. This fluorescence-based assay could be readily implemented into a high throughput format for screening compound libraries for inhibitors or activators of $\mathrm{H}_{2} \mathrm{~S}$ production.

Synthesis and fluorescent measurements of SFP-2. To further test the general applicability of the sulphide-trapping chemical strategy and to develop a fluorescent probe with visible-wavelength excitation and emission, we employed 4,4-Difluoro-1,3,5,7-tetramethyl-4bora-3a,4a-diaza-s-indacene (BODIPY) as the second fluorophore template owing to its high brightness and photostability ${ }^{17}$. We synthesized the BODIPY-based probe SFP-2 (20) as shown in Figure 3. The final probe 20 (SFP-2) was characterized by NMR and mass spectrometry (Supplementary Fig. S7). We expected a turn-on response of the probe after reacting with sulphide to afford 20a (Fig. 4). We also isolated product 20a and confirmed its molecular formula by high-resolution mass spectrometry (Supplementary Fig. S8). We evaluated this new SFP-2 probe $(5 \mu \mathrm{M})$ with $\mathrm{Na}_{2} \mathrm{~S}(50 \mu \mathrm{M})$ as an aqueous sulphide source at $37^{\circ} \mathrm{C}$ in $20 \mathrm{mM}$ PBS buffer ( $\mathrm{pH} 7.0$ ) (Fig. 4a, Supplementary Fig. S9). SFP-2 showed a $>13$-fold increase of the fluorescence intensity in the emission maximum at $510 \mathrm{~nm}$ when excited at $465 \mathrm{~nm}\left(\varepsilon=47,100 \mathrm{M}^{-1} \mathrm{~cm}^{-1}, \Phi=0.208\right)$. The high optical brightness of the probe allows for detection of free sulphide without undergoing the full intensity change.

We further examined the sensitivity of SFP-2 for sulphide. The fluorescent intensity increased by $2.6-16$ folds with addition of 5-100 $\mu \mathrm{M} \mathrm{Na}_{2} \mathrm{~S}$ (Fig. 4b; Supplementary Figs S10, S11). The turnon fluorescence response is also highly selective for sulphide versus various biological relevant thiols in the PBS buffer (Fig. 4c). The SFP2 probe is $\sim 260$-fold more selective towards $\mathrm{Na}_{2} \mathrm{~S}$ than to cysteine, and $\sim 150$-fold more selective for $\mathrm{Na}_{2} \mathrm{~S}$ than for glutathione. Direct response towards $\mathrm{H}_{2} \mathrm{~S}$ was also tested. After addition of $1 \mu \mathrm{H}_{2} \mathrm{~S}$ buffered solution (10 min $\mathrm{H}_{2} \mathrm{~S}$ bubbling), a significant fluorescence increase was observed after $5 \mathrm{~s}$ to $20 \mathrm{~min}$ of mixing, and the reaction was complete in 20 min at $25^{\circ} \mathrm{C}$ (Fig. 4d). A smaller amount of $\mathrm{H}_{2} \mathrm{~S}$ can still induce a significant response, further confirming that SFP-2 probe is a sensitive and selective probe for $\mathrm{H}_{2} \mathrm{~S}$ detection (Supplementary Fig. S12).

Cellular imaging experiments. Additionally, we tested the utility of both probes for live-cell imaging of sulphide. Even at high concentrations of SFP-1 $(50 \mu \mathrm{M})$, adverse effects of the probe on cell viability were minimal (Supplementary Fig. S13). HeLa cells were incubated with either probe for $15 \mathrm{~min}$ before replacing the culture medium with fresh medium containing varying concentrations of $\mathrm{Na}_{2} \mathrm{~S}$. Whereas some background fluorescence was observed even in the absence of added sulphide for $10 \mu \mathrm{M}$ of SFP-1 (Fig. 5a), the signal intensity increased as the concentration of sulphide was increased from 10 to $100 \mu \mathrm{M}$ (Fig. 5b-d). SFP-2 $(2 \mu \mathrm{M})$ responded at slightly higher concentrations of $\mathrm{Na}_{2} \mathrm{~S}$, with the sulphide concentration ranging from 0 to $200 \mu \mathrm{M}$ (Fig. $5 \mathrm{e}-\mathrm{h}$ ). However, SFP-2 is a brighter probe and excites and emits at visible range that is desirable for cell-based imaging. These results demonstrate that these probes are selective for sulphide and amenable for live-cell imaging.

In addition to supplementing cells with extraneous sources of sulphide, we sought to determine whether we could detect intrinsically produced $\mathrm{H}_{2} \mathrm{~S}$ by perturbing the pool of precursors to $\mathrm{H}_{2} \mathrm{~S}$ biosynthesis inside the cell. The amino acid cysteine and glutathione (reduced) (GSH) can both serve as potential sulphide sources. The previously mentioned enzymes, CBS and cystathionine $\gamma$-lyase, both use cysteine as a substrate for $\mathrm{H}_{2} \mathrm{~S}$ production ${ }^{8,9,18-20}$. GSH can be broken down by $\gamma$-glutayml transpeptidase and a dipeptidase to give cysteine $\mathrm{e}^{21-23}$, which can then be converted to $\mathrm{H}_{2} \mathrm{~S}$. Therefore, we tested whether a perturbation of the intracellular levels of either cysteine, or GSH could result in an increased cellular concentration of $\mathrm{H}_{2} \mathrm{~S}$. Imaging experiments were carried out with SFP-2, as previously described, and cells were incubated with either $100 \mu \mathrm{M}$ 
<smiles>CC(=O)/C=C/c1cc(C2=C3c4c(C)cc(C)n4B(F)N3C(C)=CC(C)=C2C)ccc1C=O</smiles>

20 (SFP-2)<smiles></smiles>
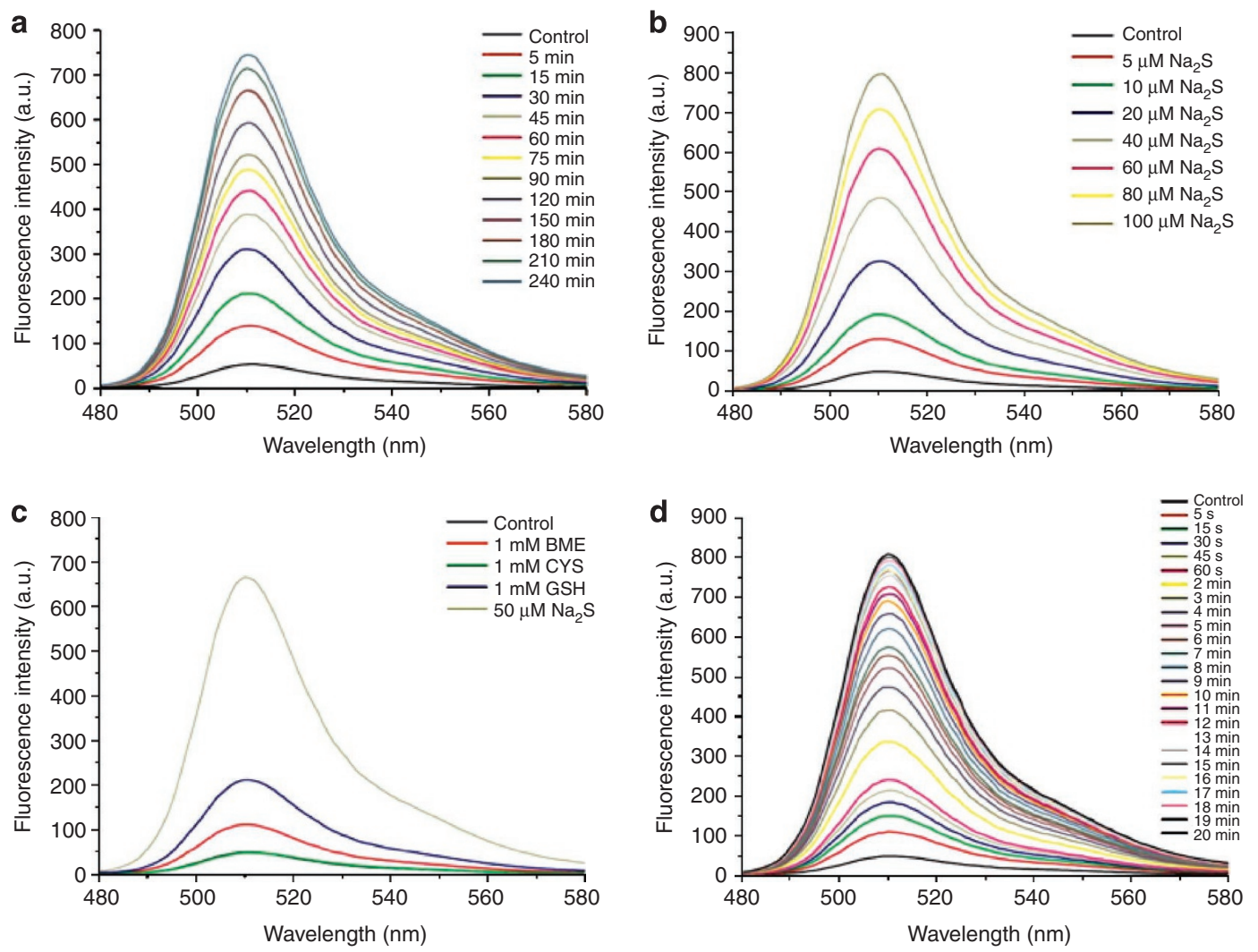

Figure 4 | SFP-2 reacts with sulphide to give a turn-on fluorescence response. (a-c) Fluorescence spectra of the SFP- 2 probe ( $5 \mu \mathrm{M})$ in PBS buffer ( $20 \mathrm{mM}, \mathrm{pH} 7.0,1 \% \mathrm{DMSO}$ ) at $37^{\circ} \mathrm{C}$. Excitation: $465 \mathrm{~nm}$, emission: $480-580 \mathrm{~nm}$. The data represent the average of three independent experiments. (a) Incubated with $50 \mu \mathrm{M} \mathrm{Na}_{2} \mathrm{~S}$ after 5, 15, 30, 45, 60, 75, 90, 120, 150, 180 and 240 min. (b) Incubated with different concentrations of $\mathrm{Na}_{2} \mathrm{~S}$ (5, 10, 20, $40,60,80$ and $100 \mu \mathrm{M}$ ) for $120 \mathrm{~min}$. (c) Incubated with various thiols at $1 \mathrm{mM}$ (BME, 2-mercaptoethanol; CYS, cysteine; GSH, glutathione) for 180 min.

(d) Incubated with $1 \mu \mathrm{l} \mathrm{H}_{2} \mathrm{~S}$ buffer (bubbling $\mathrm{H}_{2} \mathrm{~S} 10$ min-saturated solution) at $25^{\circ} \mathrm{C}$ from $5 \mathrm{~s}-20 \mathrm{~min}$.

GSH or cysteine. After 30 min of incubation, addition of both thiol species elicited a significant response rivalling that observed for $\mathrm{Na}_{2} \mathrm{~S}$ (Fig. 6). Other biologically relevant sulphur sources, including a thioether and a disulphide, did not generate a similar response (Supplementary Fig. S14). These results further indicate that these probes are capable of detecting not only external sulphides supplemented to cell cultures, but also sulphides biologically produced by the cells.

To generate a significant response for both SFP-1 and SFP-2, higher concentrations of $\mathrm{Na}_{2} \mathrm{~S}$ are required for the live-cell imaging experiments than the in vitro experiments. We reason that sodium sulphide, with its high charge density, could have difficulty passing through the cell membrane. The addition of this extraneous sulphide may lead to a much smaller fluctuation of the free sulphide level inside cells. With GSH and cysteine, $1 \mathrm{mM}$ of either thiol gave a very weak response for SFP-1 and SFP-2 in vitro (Figs $2 \mathrm{c}$ and $4 \mathrm{c}$ ), whereas only $100 \mu \mathrm{M}$ of each elicited a significant response approximating that of $\mathrm{Na}_{2} \mathrm{~S}$ in vivo. Considering the inability of the probe to detect cysteine or GSH in vitro and the millimolar concentrations of thiols already existing inside cells, we believe the response is a result of the free sulphide generated intracellularly owing to a response to the perturbed cellular levels of cysteine or GSH. We suspect that supplementing extra amounts of glutathione may disrupt glutathione homeostasis and $\mathrm{H}_{2} \mathrm{~S}$ biogenesis, leading to an increased level of $\mathrm{H}_{2} \mathrm{~S}$. Thus, the probe shows great promise as a reporter for monitoring sulphide fluctuation inside cells, and could help elucidating pathways for sulphide production and uncovering new genes responsible for sulphide homeostasis.

\section{Discussion}

The development of innovative fluorescent imaging probes has revolutionized cell biology, allowing localization and dynamic monitoring of cellular metabolite and inorganic ion pools ${ }^{15,16,24-29}$. A significant bottleneck in the emerging field of $\mathrm{H}_{2} \mathrm{~S}$ /aqueous sulphide signalling is the absence of technology for effective in vivo detection and imaging, a problem that is exacerbated by the high 

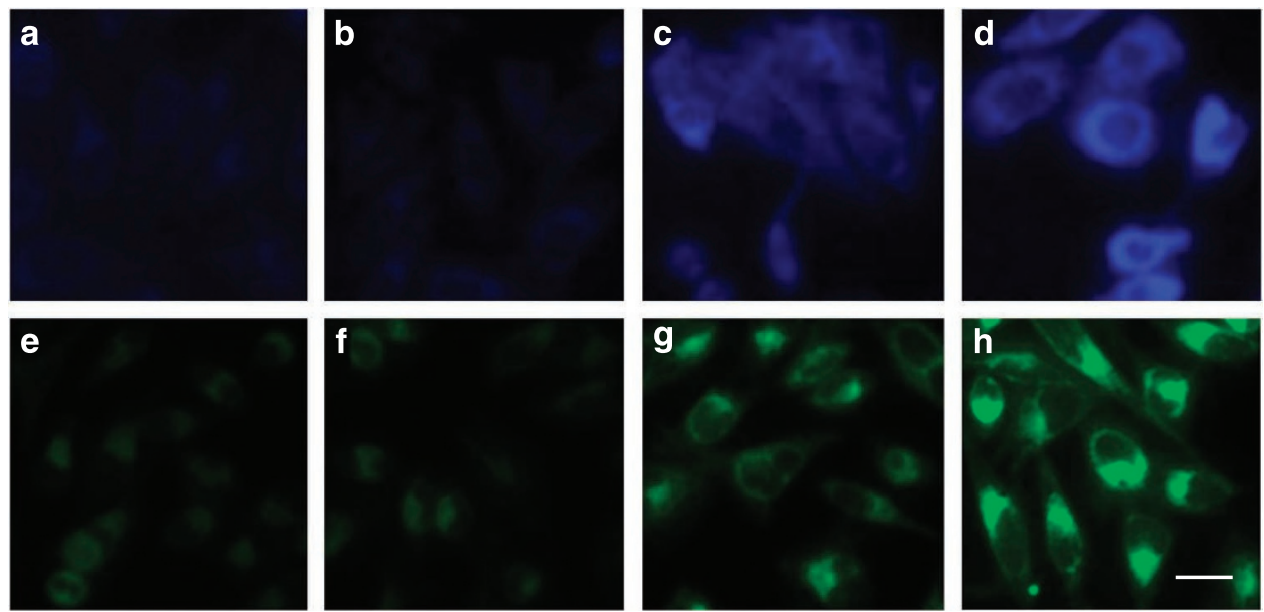

Figure $\mathbf{5}$ | Response of the probes with increasing concentrations of $\mathbf{N a}_{\mathbf{2}} \mathbf{S}$. (a-d) Imaging of aqueous sulphide in HeLa cells after 15 min incubation using SFP- 1 (12) or SFP-2 (20). For 12, excitation and data collection were performed using the corresponding filters for DAPI (blue) on a DSU spinning disk confocal. For 20, similar experiments were performed using the filter for green fluorescent protein (green). Images were obtained by using widefield fluorescence capture with SFP-1 $(10 \mu \mathrm{M})$, with increasing concentrations of $\mathrm{Na}_{2} \mathrm{~S}$ : (a) $0 \mu \mathrm{M},(\mathbf{b}) 10 \mu \mathrm{M},(\mathbf{c}) 50 \mu \mathrm{M}$, and (d) $100 \mu \mathrm{M}$. With SFP-2 (2 $\left.\mu \mathrm{M}\right)$, confocal fluorescence capture was utilized, and $\mathrm{Na}_{2} \mathrm{~S}$ concentrations were varied from (e) $0 \mu \mathrm{M},(\mathbf{f}) 50 \mu \mathrm{M},(\mathbf{g}) 100 \mu \mathrm{M}$, and (h) $200 \mu \mathrm{M}$. Scale bar represents $20 \mu \mathrm{m}$.
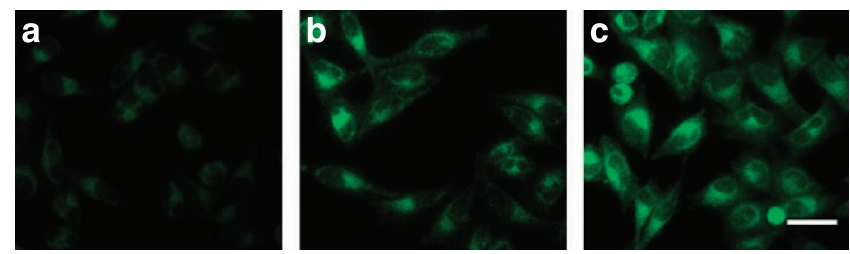

Figure 6 | Response of SFP-2 using different thiol substrates. (a-c)

Imaging of sulphide substrates in HeLa cells after 30 min incubation using SFP-2 (20). Images were obtained by using confocal fluorescence capture with $2 \mu \mathrm{M}$ probe, with either: (a) $0 \mu \mathrm{M}$ sulphide source, (b) $100 \mu \mathrm{M} \mathrm{GSH}$, (c) $100 \mu \mathrm{M}$ cysteine. Scale bar represents $40 \mu \mathrm{m}$.

intracellular thiol concentration. In this study, we have successfully developed a chemical strategy for selective sulphide detection, which can be used to monitor sulphide generation from enzymes and for cell-based sulphide imaging in live cells in the presence of large excess of thiols. Tandem chemical reactions, consisted of a sulphide addition to an aldehyde and the resulting hemithioacetal performing a Michael addition to an unsaturated acrylate ester to form a thioacetal at neutral $\mathrm{pH}$ in aqueous solution, provide the basis for the sulphide selectivity. We show that the same chemistry can be readily adapted to different fluorescent templates for sulphide detection and imaging. The same chemistry will lead to new probes with faster response, which may help to monitor fluctuations of $\mathrm{H}_{2} \mathrm{~S}$ in situ. Further optimization and utilization of this strategy and this class of probes should dramatically accelerate future studies of $\mathrm{H}_{2} \mathrm{~S}$ in biology.

\section{Methods}

Probe synthesis. Detailed description of the synthesis of each probe can be found in the Supplementary Methods. Each step was characterized by thin-layer chromatography, high-resolution mass spectra, and both ${ }^{1} \mathrm{H}$ and ${ }^{13} \mathrm{C}$ NMR (Supplementary Figs S15-S54).

Fluorometric analysis. All fluorescence measurements were carried out at room temperature on a Varian Cary Eclipse fluorescence spectrophotometer. Samples were excited at 300 and $465 \mathrm{~nm}$ with the excitation and emission slit widths set at 5 and $10 \mathrm{~nm}$ for SFP-1 and SFP-2, respectively. The emission spectrum was scanned from 310 to $550 \mathrm{~nm}$ and from 480 to $580 \mathrm{~nm}$ at $120 \mathrm{~nm} \mathrm{~min}^{-1}$, respectively. The photomultiplier voltage was set at $1,000 \mathrm{~V}$ for SFP- 1 and $600 \mathrm{~V}$ for SFP-2. The probe was dissolved in $\mathrm{CH}_{3} \mathrm{CN}$ or dimethylsulphoxide (DMSO) to make a $10 \mathrm{mM}$ stock solution, which was diluted to the required concentration for measurement.
Cytotoxicity assay. HeLa cells were grown up in DMEM media with $10 \%$ FBS and penicillin/streptomycin (Invitrogen). Cells were allowed to grow to $80 \%$ confluency before being collected using trypsin-EDTA. The cell number was determined and solution was diluted to a final concentration of $2.22 \times 10^{5} \mathrm{cells} \mathrm{ml}^{-1}$ in the aforementioned media. A final number of $2 \times 10^{4}$ cells $(90 \mu \mathrm{l})$ was transferred to each well in a 96-well plate (BD Falcon). Cells were incubated overnight at $37^{\circ} \mathrm{C}$ in a $5 \% \mathrm{CO}_{2}$ atmosphere. A serial dilution on SFP-1 was performed in DMEM media, with $10 \mu \mathrm{l}$ added to each well to give final concentrations of $0.4,0.8,1.6,3.1,12.5,25,50$ and $100 \mu \mathrm{M}$ probe. Cells were allowed to incubate for $20 \mathrm{~h}$. Wells containing only cells and only probe were also set up to serve as positive and negative controls.

Dye solution and stop/solubilization mix were obtained from a CellTiter 96 non-radioactive cell proliferation assay (Promega). Cytotoxicity assay was performed as per manufacturer's instructions. Absorbance at 570 was monitored using a Synergy plate reader (Biotek). Data was collected for three separate serial dilutions and averaged.

Cellular imaging experiments. HeLa cells were grown, as previously described. Cells were allowed to grow to $80 \%$ confluency before being collected and transferred to a 6-well plate (BD Falcon). These cells were allowed to grow overnight at $37^{\circ} \mathrm{C}$ in a $5 \% \mathrm{CO}_{2}$ atmosphere. Cells were maintained at these conditions until immediately before imaging experiments. At this time, a final concentration of $10 \mu \mathrm{M}$ SFP- 1 or $2 \mu \mathrm{M}$ SFP- 2 was added to the cells and they were allowed to incubate at the previous conditions for $15 \mathrm{~min}$. Media was then removed, and fresh media was added to remove any probe left in solution and optimize the background signal. The sulphur source was then added $\left(\mathrm{Na}_{2} \mathrm{~S}\right.$, cysteine, or GSH) to the desired concentration and cells were incubated for 15-30 $\mathrm{min}$ at room temperature before imaging

All imaging experiments were performed on a fixed cell DSU spinning confocal microscope (Olympus). Widefield fluorescence capture was used to visualize SFP-1 under all conditions. Excitation and emission monitored using the 4',6-diamidino2-phenylindole dihydrochloride (DAPI) filters provided with the scope, set at 387 per $11 \mathrm{~nm}$ and 440 per $40 \mathrm{~nm}$, respectively. Confocal fluorescence capture was used to visualize SFP-2. Excitation and emission were monitored using green filter provided with the scope, set at 485 per $20 \mathrm{~nm}$ and 525 per $30 \mathrm{~nm}$, respectively. Imaging performed using either the X20 or X40 dry objectives that are provided with the scope. Images were captured using Slidebook software.

\section{References}

1. Szabó, C. Hydrogen sulphide and its therapeutic potential. Nat. Rev. Drug Discov. 6, 917-935 (2007).

2. Kabil, O. \& Banerjee, R. The redox biochemistry of $\mathrm{H}_{2}$ S. J. Biol. Chem. 285, 21903-21907 (2010)

3. Yang, G. et al. $\mathrm{H}_{2} \mathrm{~S}$ as a physiologic vasorelaxant: hypertension in mice with deletion of cystathionine $\gamma$-lyase. Science 322, 587-590 (2008).

4. Elrod, J. W. et al. Hydrogen sulfide attenuates myocardial ischemia-reperfusion injury by preservation of mitochondrial function. Proc. Natl Acad. Sci. USA 104, 15560-15565 (2007).

5. Blackstone, E. \& Roth, M. B. Suspended animation-like state protects mice from lethal hypoxia. Shock 27, 370-372 (2007).

6. Zanardo, R. C. et al. Hydrogen sulfide is an endogenous modulator of leukocyte-mediated inflammation. FASEB J. 20, 2118-2120 (2006). 
7. Blackstone, E., Morrison, M. \& Roth, M. B. Hydrogen sulfide induces a suspended animation-like state in mice. Science 308, 518 (2005).

8. Singh, S., Padovani, D., Leslie, R. A., Chiku, T. \& Banerjee, R. Relative contributions of cystathionine beta-synthase and gamma-cystathionase to $\mathrm{H}_{2} \mathrm{~S}$ biogenesis via alternative trans-sulfuration reactions. J. Biol. Chem. 284, 22457-22466 (2009)

9. Chiku, T. et al. $\mathrm{H}_{2} \mathrm{~S}$ biogenesis by human cystathionine gamma-lyase leads to the novel sulfur metabolites lanthionine and homolanthionine and is responsive to the grade of hyperhomocysteinemia. J. Biol. Chem. 284, 11601-11612 (2009).

10. Shibuya, N. et al. 3-mercaptopyruvate sulfurtransferase produces hydrogen sulfide and bound sulfane sulfur in the brain. Antioxid. Redox Signal. 11, 703-714 (2009).

11. Jacobs, M. B., Braverman, M. M. \& Hochheiser, S. Ultra-micro determination of sulphides in air. Anal. Chem. 29, 1349-1351 (1957).

12. Whitfield, N. L., Kreimier, E. L., Verdial, F. C., Skovgaard, N. \& Olson, K. R. Reappraisal of $\mathrm{H}_{2} \mathrm{~S} /$ sulfide concentration in vertebrate blood and its potential significance in ischemic preconditioning and vascular signaling. Am. J. Physiol. Regul. Integr. Comp. Physiol. 294, 1930-1937 (2008).

13. Olson, K. R. Is hydrogen sulphide a circulating 'gasotransmitter' in vertebrate blood? Biochim. Biophys. Acta 1787, 856-863 (2009).

14. Lippert, A. R., New, E. J. \& Chang, C. J. Reaction-based fluorescent probes for selective imaging of hydrogen sulfide in living cells. J. Am. Chem. Soc. 133, 10078-10080 (2011).

15. Yi, L. et al. A highly sensitive fluorescence probe for fast thiol-quantification assay of glutathione reductase. Angew. Chem. Int. Ed. Engl. 48, 4034-4037 (2009).

16. Cody, J., Mandal, S., Yang, L. \& Fahrni, C. J. Differential tuning of the electron transfer parameters in 1,3,5-triarylpyrazolines: a rational design approach for optimizing the contrast ratio of fluorescent probes. J. Am. Chem. Soc. 130, 13023-13032 (2008)

17. Loudet, A. \& Burgess, K. BODIPY dyes and their derivative: syntheses and spectroscopic properties. Chem. Rev. 107, 4891-4932 (2007).

18. Abe, K. \& Kimura, H. The possible role of hydrogen sulfide as an endogenous neuromodulator. J. Neurosci. 16, 1066-1071 (1996).

19. Chen, X., Jhee, K. \& Kruger, W. D. Production of the neuromodulator $\mathrm{H}_{2} \mathrm{~S}$ by cystathionine $\beta$-synthase via the condensation of cysteine and homocysteine. J. Biol. Chem. 279, 52082-52086 (2004).

20. Wang, R. The gasotransmitter role of hydrogen sulfide. Antioxid. Redox Signal. 5, 493-501 (2003)

21. Griffith, O. W., Bridges, R. \& Meister, A. Evidence that the $\gamma$-glutamyl cycle functions in vivo using intracellular glutathione: effects of amino acids and sélective inhibition of enzymes. Proc. Natl Acad. Sci. USA 75, 5405-5408 (1978).

22. Kumar, T. R. et al. Reproductive defects in $\gamma$-glutamyl transpeptidase deficient mice. Endocrinology 141, 4270-4277 (2000).

23. Lieberman, M. W. et al. Growth retardation and cysteine deficiency in $\gamma$-glutamyl transpeptidase deficient mice. Proc. Natl Acad. Sci. USA 93 7923-7926 (1996).
24. Giepmans, B. N., Adams, S. R., Ellisman, M. H. \& Tsien, R. Y. The fluorescent toolbox for assessing protein locations and function. Science 312, 217-224 (2006).

25. McQuade, L. E. \& Lippard, S. J. Fluorescent probes to investigate nitric oxide and other reactive nitrogen species in biology. Curr. Opin. Chem. Biol. 14, 43-49 (2010).

26. Tomat, E. \& Lippard, S. J. Imaging mobile zinc in biology. Curr. Opin. Chem. Biol. 14, 225-230 (2010).

27. Miller, E. W. \& Chang, C. J. Fluorescent probes for nitric oxide and hydrogen peroxide in cell signaling. Curr. Opin. Chem. Biol. 11, 620-625 (2007).

28. Que, E. L., Domaille, D. W. \& Chang, C. J. Metals in neurobiology: probing their chemistry and biology with molecular imaging. Chem. Rev. 108, 1517-1549 (2008).

29. Taki, M., Wolford, J. L. \& O'Halloran, T. V. Emission ratiometric imaging of intracellular zinc: design of a benzoxazole fluorescent sensor and its application in two-photon microscopy. J. Am. Chem. Soc. 126, 712-713 (2004).

\section{Acknowledgements}

We thank Dr G. Jia for help with mammalian cell cultures, Dr C. Labno for assistance in all imaging experiments, Dr J. Wang for advice on the probe synthesis, and Ms S.F. Reichard for editing. This work was supported in part by the US National Science

Foundation International Collaboration in Chemistry between US Investigators and their Counterparts Abroad (CHE-0922998/NSFC 20921120404 to C.H.) and the National Institutes of Health (HL58984 to R.B.). Y.Q. is partially supported by the China Scholar Program. J.K. was supported by a Chemistry-Biology Interface Predoctoral Training Grant. S.Y.Z. is supported by Natural Science Foundation of China (NSFC 20921120404).

\section{Author contributions}

C.H. conceived the idea and directed the work. Y.Q., J.K., J.Z., O.K., R.B. and C.H. designed experiments. Y.Q. performed the synthesis and in vitro tests with help from S.Y.Z. J.K. performed cell-based imaging. O.K. performed enzymatic $\mathrm{H}_{2} \mathrm{~S}$ biogenesis assay. All authors contributed to data analysis and manuscript writing.

\section{Additional information}

Supplementary Information accompanies this paper at http://www.nature.com/ naturecommunications

Competing financial interests: The University of Chicago Office of Technology and Intellectual Property is in the process of filing a patent protection of the reported probe design and the method.

Reprints and permission information is available online at http://npg.nature.com/ reprintsandpermissions/

How to cite this article: Qian, Y. et al. Selective fluorescent probes for live-cell monitoring of sulphide. Nat. Commun. 2:495 doi: 10.1038/ncomms1506 (2011). 